\title{
METODE PENGUKURAN PROBABILITAS KEBANGKRUTAN BANK DAN ANALISIS HUBUNGANNYA DENGAN DIVERSIFIKASI SUMBER PENDAPATAN: KASUS PERBANKAN INDONESIA
}

\author{
Buddi Wibowo \\ Program Pascasarjana Ilmu Manajemen, Fakultas Ekonomi dan Bisnis, Universitas Indonesia \\ email: buddi.wibowo@ui.ac.id
}

\begin{abstract}
ABSTRAK
Metode pengukuran probabilitas kebangkrutan bank adalah masalah riset klasik. Metode pengukuran menggunakan analisis diskriminan dan model logit seperti Altman's Z score dan Model Ohlson tidak memiliki dasar teoretik keuangan yang memadai karena variable-variabel yang ada di dalam model dipilih secara arbitrer dan sangat tergantung pada data yang digunakan untuk mengestimasinya. Model Merton adalah model pengukuran probabilitas default yang diakui secara luas sebagai model yang memiliki dasar teoretik yang kuat namun memiliki masalah tersendiri pada implementasinya karena variabel yang digunakannya bersifat unobservable. Probabilitas default sendiri dipengaruhi oleh tingkat diversifikasi pendapatan bank. Beberapa riset menghasilkan kesimpulan yang bertentangan. Pada perbankan Indonesia hubungan antara kedua variable tersebut bersifat kuadaratik ( $U$ shape) dimana diversifikasi yang natural awalnya dapat menurunkan probabilitas default bank, namun sampai suatu titik diversifikasi yang terlampau tinggi justru mendorong probabilitas default menjadi naik.
\end{abstract}

Kata Kunci: Bank, risiko, probabilitas kebangkrutan, diversifikasi

\begin{abstract}
Bank's probability of default measurement method is one of the classic research problem. The measurement methods using discriminant analysis and logit models such as Altman's Z score and Ohlson Model do not have adequate financial theoretical foundation because variables in the models are chosen arbitrarily and depend heavily on the data used in estimation. Merton's model of default probability is a measurement model that is widely recognized as a model that has a strong theoretical basis but has its own problems in its implementation because it uses unobservable variables. Default probability itself is influenced by the level ofincome diversification. Some research resulted in conflicting conclusions. We show that in Indonesian banking industry, relationship between these two variables are quadratic ( $U$ shape) which show natural diversification can reduce the bank's probability of default, until reach a infelction point that too high diversification would encourage the probability of default to be increased
\end{abstract}

Key word: Bank, risk, probability of default, diversification

\section{PENDAHULUAN}

Stabilitas sektor perbankan menjadi faktor penting dalam menjaga stabilitas sistem keuangan dan perekonomian secara luas. Investasi dapat terkendala serius ketika kemampuan bank dalam menyalurkan kredit dan menyediakan jasa keuangan dan sistem pembayaran lainnya terganggu karena kondisi keuangan internal bank mengalami masalah. Dalam ranah riset akademis, ada dua paradigma dalam melihat cara mencapai kestabilan sektor perbankan, yaitu competition-stability dan competition-fragility. Kedua paradigma tersebut memiliki rerangka pikir yang berbeda sehingga menghadirkan rekomendasi kebijakan yang berbeda (Fu et al., 2014 dan Beck et al., 2010).

Pandangan "competition-fragility" menyatakan bahwa apabila bank memiliki kekuatan yang cukup besar di pasar, maka harga saham bank di bursa saham akan meningkat sebagai cerminan meningkatnya prospek bisnis bank. Bank akan menghindari aktivitas bisnis yang berisiko tinggi karena opportunity cost yang terlalu besar mengingat posisinya yang sudah cukup baik di mata investor. Bank menjadi lebih berhati-hati dalam menyalurkan kredit, menjaga kecukupan modal sesuai aturan perbankan yang ada dan karena skala operasi semakin besar serta melayani segmen konsumen yang semakin luas, jasa yang diberikan bank makin banyak dan mulai memperbesar pendapatan non bunga. Pendapatan bank makin besar pada fee-based income. Bank menjadi terdorong untuk melakukan diversifikasi produk sehingga produk dan layanan bank yang dapat dinikmati para nasabah menjadi semakin lengkap dan semakin baik kualitasnya. Stabilitas sektor perbankan semakin meningkat ketika persaingan antar bank dibatasi oleh regulator (Fernandez et al., 2016). 
Keeley (1990) membuktikan ketatnya persaingan telah mengikis laba dan menyebabkan meningkatnya kegagalan bank di Amerika Serikat pada tahun 1980an. Penelitian ini memperkuat hipotesis bahwa ketika kompetisi semakin ketat dan margin laba bank menipis, bank akan menjadi lebih berani mengambil risiko demi untuk meningkatkan laba. Kualitas kredit bank menjadi memburuk yang membuat bank menjadi rentan terhadap segala risiko yang dihadapinya. Hellmann et al., (2000) menunjukkan kompetisi dalam memperebutkan deposito akan mengikis sikap berhati-hati bank. Penelitiannya dilakukan dengan mengobservasi krisis perbankan di Amerika Serikat dan Jepang dan mengidentifikasi perilaku bank yang mengambil risiko yang berlebihan sebagai sumber penyebab krisis. Hasil penelitiannya menunjukkan bahwa perilaku bank untuk mengambil risiko berlebihan didorong oleh liberalisasi sektor perbankan yang ditandai dengan penghapusan barriers to entry, penghapusan kebijakan penetapan plafon (ceiling) suku bunga deposito, dan kemudahan dalam membuka cabang-cabang baru. Meningkatnya kompetisi memperebutkan deposito akan mengikis profitabilitas perbankan dan mendorong munculnya insentif moral hazard yang besar untuk mengambil risiko yang besar di tengah jaminan deposito yang diberikan pemerintah.

"Competition-stability view" memiliki rerangka pikir yangberbeda dengan "competition-fragility". Kompetisi yang ketat justru dapat meningkatkan stabilitas bank. Boyd dan De Nicolo (2005) menyatakan bahwa semakin besar kekuatan (market power) sebuah bank di pasar kredit dapat menimbulkan risiko yang semakin besar karena tingkat suku bunga kredit yang semakin tinggi yang dapat membuat peminjam menjadi lebih sulit untuk membayar kredit tersebut dan meningkatkan moral hazard para peminjam untuk menggunakan dana kredit tersebut ke dalam proyek-proyek yang lebih berisiko. Bank yang memiliki kekuatan pasar yang besar akan cenderung menetapkan suku bunga pinjaman yang lebih tinggi bank yang terlalu besar dan dominan di dalam sebuah industri perbankan juga cenderung mengambil risiko yang jauh lebih tinggi jika bank tersebut menyadari bahwa selalu dibantu oleh pemerintah (bail out) karena akan memiliki dampak sistemik yang serius terhadap sektor perbankan bahkan terhadap perekonomian secara luas (Too Big Too Fail). Beberapa riset empirik menunjukkan hasil yang sejalan dengan pandangan ini, misalnya, Boyd et al., (2006) menemukan $\mathrm{Z}$ index, sebuah ukuran inverse dari risiko bank menurun bersamaan dengan meningkatnya konsentrasi industri perbankan. Schaeck et al., (2006) menemukan semakin tinggi tingkat kompetisi perbankan, semakin rendah kemungkinan kegagalan bank.

Menurut pandangan "competition-stability", stabilitas perbankan justru akan memburuk ketika tingkat persaingan antar bank menurun. Bank yang menguasai pasar cenderung menetapkan suku bunga kredit yang realtif jauh lebih tinggi. Tingkat suku bunga kredit yang tinggi memunculkan adverse selection di dalam proses penyaluran kredit perbankan, nasabah bank yang mengajukan kredit hanya mereka yang berisiko tinggi karena nasabah yang memiliki risiko yang rendah cenderung menghindari pembiayaan dari bank dan mencari sumber pendanaan lain yang lebih murah. Stiglitz dan Weiss (1981) menunjukkan suku bunga yang tinggi akan meningkatkan risiko portofolio kredit perbankan karena adanya adverse selection pada proses penyaluran kredit bank sehingga proyekproyek yang dibiayai bank tergolong proyek yang buruk kualitasnya. Tingginya biaya dana yang harus ditanggung perusahaan akan mendorong para calon peminjam yang rendah risikonya menghindari pendanaan perbankan dan mencari sumber pendanaan lain melalui pasar modal dengan cost of fund yang jauh lebih rendah. Calon peminjam yang tidak dapat mengakses pendanan selain dari perbankan, umumnya karena risiko bisnis dan proyek mereka yang berisiko tinggi sehingga tidak menarik minat investor di pasar modal, menjadi nasabah bank yang menerima kucuran kredit perbankan. Probabilitas kebangkrutan perusahaan yang diberikan kredit oleh bank menjadi relatif tinggi dan sensitif terhadap perubahan ekonomi dan siklus bisnis. Jumlah kredit macet perbankan cenderung meningkat dan mengancam stabilitas sistem perbankan.

Stiroh (2006) serta Stiroh dan Rumble (2006) menemukan risiko bank meningkat bersamaan dengan meningkatnya proporsi pendapatan non bunga. Persentase pendapatan non bunga yang tinggi menyebabkan volatilitas laba bank semakin tinggi. De Young dan Torna (2013) membuktikan diversifikasi sumber pendapatan bank menjadi penyebab utama kegagalan bank pada saat krisis ekonomi yang melanda Amerika Serikat tahun 2008. De Young dan Torna (2013) juga menunjukkan diversifikasi pendapatan memberikan dampak berbeda antar bank tergantung kondisi keuangan bank, misalnya jumlah capital buffer, NPL, dan model bisnisnya. Bank yang sehat dan memiliki basis nasabah yang kuat memperoleh manfaat yang signifikan dengan melakukan diversifikasi pendapatan sehingga tidak terlampau tergantung pada pendapatan 
tradisional bank berupa bunga kredit yang sangat dipengaruhi oleh kondisi perekonomian dan siklus bisnis yang menerpa nasabahnya. Sebaliknya bankbank yang kurang memiliki daya dukung pemodalan yang kuat yang dibutuhkan untuk membangun infrastruktur bank yang lebih canggih dengan teknologi dan daya dukung SDM yang lebih mahal untuk memperoleh pendapatan non bunga, serta basis nasabah yang labil dan mudah beralih ke bank pesaing akan justru semakin berisiko ketika memutuskan untuk mendiversifikasi sumber pendapatannya.

Lepetit et al. (2008) yang meneliti bank-bank Eropa menunjukkan hasil yang mirip dengan apa yang ditemukan DeYoung dan Torna (2013) dan Stiroh dan Rumble (2006) di Amerika Serikat. Bankbank Eropa yang memiliki persentase pendapatan non bunga yang tinggi cenderung memiliki probabilitas default yang tinggi dibandingkan bank yang fokus pada bisnis bank yang konvensional yaitu penyaluran kredit. Hubungan positif antara diversifikasi dan probabilitas kegagalan bank terutama ada pada bank-bank kecil di Eropa yang bergantung pada komisi dan imbalan jasa bank. Mercieca et al. (2007) membuktikan bank-bank kecil di Eropa tidak mendapatkan manfaat dari diversifikasi. Semakin tinggi proporsi pendapatan non bunga justru semakin rendah stabilitas bank dan semakin rendah pula tingkat profitabilitas bank, setidaknya jika diukur dari risk-adjusted profits.

Meslier et al. (2014) membuktikan hal yang bertentangan dengan temuan di Marika dan Eropa yaitu diversifikasi pendapatan dan diversifikasi jenis kredit yang disalurkan sebuah bank tebukti dapat meningkatkan stabilitas bank jika stabilitas bank diukur dengan $\mathrm{Z}$ score yang mencerminkan stabilitas bank secara keseluruhan (risk adjusted bank's profitability). Diversifikasi sumber pendapatan dapat menstabilkan tingkat profitabilitas bank karena pendapatan non bunga tidak berkaitan erat dengan kredit yang disalurkan bank sebuah ciri yang unik yang ada di negara berkembang seperti yang ditemukan Meslier et al. (2014) di Filipina.

Menurut Berger et al. (2009) menjadi sangat penting untuk menggunakan ukuran risiko bank yang secara akurat dapat merefleksikan risiko kredit atau risiko bank sehingga uji empirik atas hubungan kompetisi dan stabilitas bank dapat secara tajam menunjukkan bukti apakah paradigma competitionstability atau competition-fragility yang sesuai dengan fakta lapangan. Beberapa riset sebelum ini seperti misalnya Fernandez, Gonzalez dan Suarez (2016), Carretta et al. (2015) dan Carletti dan
Hartman (2003) menggunakan Z-index sebagai sebuah inverse proxy untuk risiko bank secara keseluruhan. Z-index adalah rasio antara jumlah rata-rata ROA dan ekuitas bank dengan volatilitas ROA. Z-index lebih tepat mencerminkan stabilitas tingkat keuntungan bank, bukan probabilitas kemungkinan kegagalan bank. Beberapa riset yang lain, seperti Boyd et al. (2006) menggunakan kredit macet yang mencerminkan risiko portofolio kredit bank saja sebagai ukuran stabilitas bank. Carretta et al. (2015) menggunakan baik $\mathrm{Z}$ score maupun rasio NPL karena kedua ukuran stabilitas bank tersebut memiliki aspek stabilitas yang berbeda. $\mathrm{Z}$ score mengukur stabilnya pencapaian risk-adjusted profitability dari bank, sementara rasio NPL mencerminkan risiko kredit yang merupakan hasil dari risk taking behavior setiap bank. Terdapat kritik terhadap penggunaan Z-index dan NPL yaitu kedua ukuran tersebut hanya memberikan sebuah indikasi, tidak mampu secara tajam dan langsung mengukur berapa besar probabilitas kegagalan sebuah bank.

Model prediksi kebangkrutan yang paling klasik adalah model Altman (1968). Pendekatan yang digunakan Altman (1968) adalah dengan menggunakan metode multi discriminant analysis. Berbasis analisis data 66 perusahaan Amerika Serikat yang terbagi menjadi dua kelompok sama besar antara perusahaan yang bangkrut dan yang tidak bangkrut selama periode 1946-1965, Altman memperoleh persamaan linier yang dapat memprediksi kebangkrutan perusahaan. Persamaan linier Altman berisi rasio keuangan perusahaan. Nilai yang berhasil diperoleh dari persamaan linier diskriminan berisi lima rasio keuangan model Altman disebut Altman's Zscore. Z-score yang semakin tinggi mencerminkan risiko kebangkrutan yang makin rendah. Apabila $\mathrm{Z}$ $<1.80$ maka probabilita kebangkrutan perusahaan tersebut dalam periode 2 tahun ke depan cukup tinggi. Kritik terhadap model Altman terutama pada pemilihan rasio keuangan yang arbitrer dan tidak memiliki kerangka logika keuangan yang memadai (Martin, 1996)

Model prediksi kebangkrutan yang lain adalah model berbasis model probabilitas linear seperti model Logit, Probit dan Normit. Ohlson (1980) menjadi yang pertama menggunakan model Logit untuk memprediksi perusahaan non keuangan. Martin (1996) menggunakan model Logit sebagai early warning system perbankan di Amerika Serikat. Hadad et al. (2004) memprediksi kebangkrutan bank di Indonesia. Betz et al. (2014) memprediksi financial distress bank-bank di Eropa dengan model Logit. Kritik terhadap penggunaan model Logit 
sebagai model prediksi kebangkrutan atau kegagalan bank hampir mirip dengan kritik terhadap model discriminant analysis yaitu pembangunan model yang tidak memiliki basis intuisi dan teori keuangan yang memadai dan sangat tergantung kepada data yang bersifat ex post dan dipertanyakan generalisasinya kepada perusahaan lain atau lebih jauh lagi dapatkah diimplementasikan kepada lembaga keuangan.

Merton (1974) memperkenalkan pendekatan baru dalam pemodelan risiko kebangkrutan yaitu dengan menggunakan model kontrak opsi, BlackScholes option formula. Model prediksi kebangkrutan dengan pendekatan seperti yang ada pada Merton (1974) disebut sebagai model struktural. Model Merton memiliki keunggulan dari sisi kerangka teoritik yang lebih kuat dibandingkan dengan model prediksi default lainnya. Kendala utama dalam implementasi Model Merton secara empirik yaitu bagaimana metode estimasi nilai pasar asset perusahaan dan volatilitasnya yang bersifat unobservable. Afik et al. (2016) menampilkan metode-metode terkini yang digunakan oleh peneliti dalam menggunakan model Merton secara empirik. Model Merton diimplementasikan secara luas dalam memprediksi risiko deposit insurance di beberapa negara dalam menentukan risk-based tariff (Sundaresan, 2013).

Berbeda dengan ukuran probabilita kegagalan bank yang masih diperdebatkan di kalangan para peneliti, untuk mengukur diversifikasi pendapatan bank tidak tedapat banyak perdebatan, hampir semua peneliti seperti DeYoung dan Torna (2013) dan Stiroh dan Rumble (2006) menggunakan ukuran Income Focus, sementara diversifikasi jenis kredit yang disalurkan banyak digunakan Loan Focus.

Merujuk pada review atas literature yang telah dipaparkan di atas, maka permasalahan penelitian ini adalah apakah diversifikasi sumber pendapatan bank mempengaruhi secara signifikan stabilitas bank?, apakah hubungan antara diversifikasi pendapatan perbankan dengan stabilitas bank bersifat linier atau kuadratik (U shape)?, dan apakah terdapat perbedaan pola hubungan antara diversifikasi dengan probabilitas kepailitan bank antar kelompok bank di Indonesia? pola hubungan antara diversifikasi pendapatan dan probabilitas kebangkrutan juga akan diuji terhadap beberapa variabel kontrol seperti NPL, LDR dan capital buffer.

Model prediksi kebangkrutan yang berbasiskan discriminant analysis ada beberapa selain model Altman yaitu seperti model Taffler (1982), Beaver (1966), dan Edmister (1972). Semua model berbasis discriminant analysisitu memiliki kelemahan yang sama yaitu model yang dipilih tidak memiliki basis logika dan teori keuangan yang kuat. Model seperti ini diperoleh secara apriori dengan data ex-post dan pilihan rasio keuangan dilakukan secara arbitrer, serta koefisien dari setiap rasio keuangan di dalam model yang dihasilkan tergantung pada data yang digunakan sebagai dasar pemodelan. Generalisasi model kepada data lain menjadi permasalahan utama. Model Taffler (1982), Beaver (1966), dan Edmister (1972) berbeda dengan model Altman karena data perusahaan Amerika Serikat yang digunakan setiap peneliti tersebut berbeda-beda. Taffler (1982) memperoleh model yang berbeda untuk perusahaan di Inggris, sementara Edmister (1972) menemukan model yang berbeda untuk perusahaan dengan asset yang kecil. Model berbasis discriminant analysis seperti Altman (1968) dan yang lainnya memiliki masalah tersendiri untuk memprediksi kebangkrutan sebuah lembaga keuangan seperti bank karena rasio keuangan yang ada di dalam model lebih tepat mengukur kondisi keuangan perusahaan non keuangan, yang lebih khusus lagi hanya pada perusahaan manufaktur.

Model Altman yang digunakan untuk memprediksi kemungkinan bangkrut adalah:

$\mathrm{Z}=1,2 \mathrm{X}_{1}+1,4 \mathrm{X}_{2}+3,3 \mathrm{X}_{3}+0,6 \mathrm{X}_{4}+0,99 \mathrm{X}_{5}$ Dimana $X_{1}$ adalah Working Capital/Total Assets, $\mathrm{X}_{2}$ adalah Retained Earnings/Total Assets, $X_{3}$ adalah Earnings before Interest and Taxes/Total Assets, $\mathrm{X}_{4}$ adalah Market Value of Equity/Book Value of Debt, dan $X_{5}=$ Sales/Total Assets.

Model Altman ini merupakan persamaan discriminant yang diestimasi dari 66 perusahaan di Amerika Serikat dan Altman (1962) menunjukkan model tersebut mampu memisahkan antara perusahaan yang bangkrut dengan yang tidak.

Model prediksi Beaver (1966) juga dengan menggunakan discriminant analysis yang diperoleh dari analisis laporan keuangan 23 perusahaan yang gagal bayar surat utangnya di Amerika Serikat. Berbeda dengan Altman (1968), Beaver menemukan rasio yang dapat digunakan untuk memprediksi kegagalan sebuah perusahaan adalah cash flow ratio, net income ratio, debt-asset ratio, dan working capital ratio.

Taffler (1982) menggunakan data 32 perusahaan Inggris menemukan persamaan linier discriminant dengan empat rasio keuangan yaitu EBIT/Total asset tahun sebelumnya, Total kewajiban/net capital employed, Modal Kerja/Net worth, quick Asset / Total Asset. Model Z score Taffler adalah:

$\mathrm{Z}=0,71 \frac{\mathrm{EBIT}}{\text { Total Assett-1 }}-0,93 \frac{\text { Total Liabilities }}{\mathrm{NCE}}+0,32 \frac{\mathrm{WC}}{\mathrm{NW}}+0,49 \frac{\mathrm{QA}}{\mathrm{TA}} \ldots . .(2)$ 
Model berbasis analisis diskriminan memiliki variabel yang berbeda-beda karena penentuan variabel apa saja yang dapat memprediksi kemungkinan default bersifat arbitrer tanpa didasarkan pada teori tertentu. Altman (1968) mengakui bahwa rasio yang dipilih hanya berdasarkan banyaknya orang yang menggunakan rasio-rasio tersebut. Rasio-rasio keuangan yang dihitung dari laporan keuangan dinilai oleh banyak peneliti juga tidak mampu berfungsi sebagai alat prediksi masa depan (ex-ante) karena laporan akuntansi besifat historis atau ex post. Laporan akuntansi juga muncul dengan periode waktu yang cukup panjang, tahunan untuk yang telah diaudit, sehingga mustahil untuk mengukur dinamika probabilita default dalam jangka waktu yang lebih pendek.

Model risiko default yang lain adalah keluarga model Linear Probability. Ohlson O-Score adalah model linier dari 9 faktor risiko yang diestimasi dengan model Logit. Hadad et al. (2004) secara khusus menggunakan model Logit untuk memperoleh model prediksi kepailitan bank di Indonesia. Model probabilitas kepailitan bank Hadad et al. (2004) adalah sebagai berikut:

$$
P_{i t}=\frac{1}{1+\theta^{-Z i t}}
$$

dimana

$\mathrm{P}$ adalah probabilitas kegagalan bank, sementara $Z$ dihitung dengan persamaan berikut: $Z_{i}=-7,148+0,0004 X_{1}-0,637 X_{2}-80,24 X_{3}-0,914 X_{4}$ $+0,503 X_{5}+2,663 X_{6}-1,059 X_{7}$

Variable sampai $X_{1}$ sampai $X_{7}$ berturut-turut adalah Equity to deposit, Loan to Equity, Fixed Asset to Capital, Return to Capital, Equity Capital to Total Asset, Loan to Asset, Treasury Securities to Asset

Model Logit ini menghasilkan sebuah ukuran probabilita kebangkrutan yang lebih definitif dan terukur dibandingkan dengan model dengan basis analisis diskriminan. Namun penggunaan rasio keuangan dalam model Probabilita Linier tetap masih menimbulkan kritik yang sama yang dihadapi oleh model discriminant yaitu basis teori yang mendasari pembentukan modelnya tidak cukup memadai.

Model prediksi probabilitas kebangkrutan yang memiliki basis teori keuangan yang paling kuat adalah model Merton atau yang sering disebut sebagai model struktural. Model struktural ini menggunakan asumsi Modigliani-Miller tentang struktur kapital perusahaan yang tidak berpengaruh terhadap nilai perusahaan. Nilai perusahaan yang dimaksud dalam model Merton ini adalah nilai pasar asset perusahaan (market value of asset) yang mencerminkan prospek dan nilai bisnis perusahaan di masa depan. Nilai pasar aset sebuah perusahaan berubah-ubah sepanjang waktu tergantung pada situasi eksternal dan internal perusahaan sehingga diasumsikan bergerak secara random walk. Pilar berikutnya dalam model Merton adalah nilai pasar dari ekuitas dan hutang perusahaan dapat dimodelkan sebagai sebuah contingent claims atas asset perusahaan. Hutang perusahaan dapat dinilai sebagai sebuah kontrak opsi jual (put option) atas asset perusahaan dengan strike price sebesar nilai pokok hutang (face value of debt) dan opsi jual itu jatuh tempo pada saat jatuh temponya hutang.

Apabila nilai pasar asset $\left(V_{t}\right)$ jauh lebih besar dari pada pokok hutang yang harus dibayar pada saat jatuh tempo $\left(F_{t}\right)$ maka pemberi hutang akan menerima seluruh pokok hutangnya. Apabila nilai asset lebih rendah dari pada pokok hutang pada saat jatuh tempo, $\left(V_{t}<F_{t}\right)$ perusahaan disebut dalam keadaan default, tidak mampu membayar hutang secara penuh. Pemberi hutang (bond holder) hanya akan memperoleh sebesar nilai asset tersebut $\left(V_{t}\right)$ dan menderita kerugian sebesar $\left(F_{t}-V_{t}\right)$. Apabila bond holder memegang kontrak opsi jual dengan spesifikasi yang telah dipaparkan di atas, pada saat default, bond holder tetap dapat memperoleh pokok hutangnya secara penuh dengan mengexercise kontrak opsi jualnya yang strike price nya sebesar pokok hutang. Portfolio risky bond dengan put option dapat menjadi sebuah risk free bond. Harga kontrak opsi jual akan semakin mahal jika probabilita kebangkrutan perusahaan yang berhutang semakin tinggi. Probabilita kebangkrutan bank dapat tercermin pada probabilita di-exercise nya kontrak opsi jual tersebut atau, dalam istilah kontrak derivatif, probabilita kontrak opsi jual itu masuk ke dalam kontrak yang in-the money (Anginer, et al., 2014). Semakin besar kemungkinan kebangkrutan bank maka kontrak opsi tersebut semakin tinggi nilainya (in-the money), semakin besar pula probabilita kontrak opsi dieksekusi oleh pemegangnya. Dengan pendekatan Merton, nilai hutang perusahaan dapat dimodelkan sebagai put option sementara nilai ekuitas perusahaan dapat dimodelkan sebagai sebuahcall option.

Metode estimasi nilai pasar asset perusahaan menjadi fokus perhatian untuk dapat mengimplementasikan model Merton karena merupakan variabel yang tidak diperoleh datanya di pasar (unobserved variable). Nilai pasar saham didekati dari nilai pasar ekuitas yang dapat diketahui dari harga saham perusahaan yang diperdagangkan 
di bursa saham. Metode estimasi nilai pasar aset perusahaan dan volatilitasnya menjadi salah satu topik riset tersendiri dan masih terus berkembang dalam konteks implementasi model Merton ini (Afik, et al., 2016)

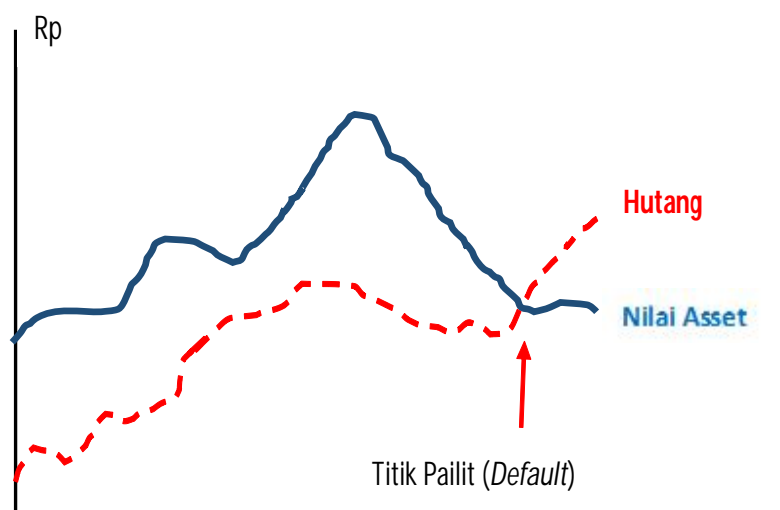

Waktu

Gambar 1. Proses Nilai Asset, Posisi Hutang dan Peristiwa Default.

Tabel 1.

Pay Off Pemegang Surat Hutang

\begin{tabular}{lccc}
\hline & \multicolumn{2}{c}{ Pailit } \\
\hline & $\begin{array}{c}\text { Tidak } \\
\text { Pailit }\end{array}$ & $\begin{array}{c}\text { Tanpa Hedge } \\
\text { Option }\end{array}$ & $\begin{array}{c}\text { Dengan } \\
\text { Hedge }\end{array}$ \\
\hline Posisi & $\mathrm{V} \geq \mathrm{F}$ & $\mathrm{V}<\mathrm{F}$ & $\mathrm{V}<\mathrm{F}$ \\
\hline $\begin{array}{l}\text { Pay Off } \\
\text { Bondholder }\end{array}$ & $\mathrm{F}$ & $\mathrm{V}$ & $\mathrm{F}$ \\
\hline
\end{tabular}

Sebagian peneliti dalam mengukur risiko default sering menggunakan ukuran distance to default yaitu selisih antara nilai pasar asset yang diestimasi dengan model Merton terhadap nilai pokok hutang yang kemudian diskala dengan standar deviasi nilai pasar asset bank Distance to default Merton telah terbukti menjadi alat prediksi default yang lebih baik dibandingkan dengan model berbasis data akuntansi (Hovakimian et al,. 2012). Dibandingkan dengan ukuran risiko bank berbasis data akuntansi seperti Z-score, distance to default yang berbasis data pasar memiliki keunggulan. Pertama, distance to default dapat dihitung dengan frekuensi lebih sering dan jangka waktu yang pendek sehingga dapat diketahui estimasi default pada titik waktu tertentu yang dibutuhkan. Informasi laporan keuangan yang telah diaudit tersedia setahun sekali atau untuk yang belum diaudit paling cepat sebulan sekali, sementara informasi bursa saham tersedia secara harian. Kedua, informasi di bursa saham biasanya bersifat forward-looking sehingga distance to default dapat mencerminkan persepsi pasar terhadap kondisi bank di masa depan.
Riset atas hubungan antara tingkat diversifikasi pendapatan bank dan stabilitas bank atau probabilitas kebangkrutan bank menghasilkan temuan yang bertentangan dengan pandangan "competitionstability". DeYoung dan Torna (2013) dan Stiroh dan Rumble (2006) menunjukkan diversifikasi pendapatan yang didorong karena bank berupaya mencari sumber pendapatan lain selain bisnis utamanya dalam penyaluran kredit berpotensi besar menyebabkan stabilitas bank menjadi terganggu. Bank yang memiliki persentase pendapatan non bunga yang tinggi cenderung memiliki probabilitas default yang tinggi dibandingkan bank yang fokus pada bisnis bank yang konvensional yaitu penyaluran kredit. Masuknya bank ke dalam aktivitas non tradisional dan melibatkan transaksi derivatif yang kompleks menjadi pintu masuk peningkatan eksposur bank tersebut terhadap risiko pasar. Diversifikasi pada awalnya memang memberikan dampak yang cukup baik terhadap pendapatan bank dimana volatilitas pendapatan bank dapat ditekan. Diversifikasi pendapatan pada tahap awal seperti ini umumnya muncul secara natural yang disebabkan permintaan dari nasabah bank terhadap jasa-jasa layanan bank yang semakin lengkap. Namun apabila proporsi pendapatan non tradisional tersebut mulai didominasi oleh pendapatan bank dari aktivitas trading surat berharga, transaksi sekuritas derivatif dan aktivitas lain yang berisiko tinggi, maka diversifikasi akan menyebabkan stabilitas bank menurun drastic dan probabilita kebangkrutan melonjak (Stiglitz dan Weiss, 1981). Hubungan antara diversifikasi dan probabilitas kegagalan bank dapat diduga bersifat seperti huruf U ( $U$ shape).

Hubungan antara diversifikasi pendapatan dan stabilitas bank dipengaruhi tiga faktor yang menjadi karakteristik sebuah bank yaitu capital buffer, NPL dan LDR bank. Bank mencadangkan capital buffer untuk menyerap potensi kerugian yang dapat terjadi sehingga posisi kewajiban penyediaan modal minimum (KPMM) dapat sesuai dengan aturan yang telah ditetapkan oleh regulator. Capital buffer yang telah dicadangkan oleh Bank diharapkan dapat meredam risiko yang muncul karena perubahan siklus bisnis. Procyclical capital buffer effect merupakan kecenderungan Bank untuk menurunkan capital buffer ketika siklus bisnis membaik dan menaikan capital buffer ketika siklus bisnis sedang memburuk (ada hubungan negatif antara capital buffer dengan siklus bisnis. Naik turunnya capital buffer karena keputusan manajerial seperti ini dapat mengancam stabilitas bank apabila terjadi peristiwa ekonomi maupun non ekonomi yang menciptakan 
risiko keuangan yang bersifat sistemik dimana secara bersamaan perusahaan-perusahaan dan bank-bank mengalami kesulitan keuangan. NPL dan LDR menunjukkan kemampuan bank dalam mengelola aktivitas pemberian kredit dan pengawasan terhadap nasabahnya serta tingkat agresivitas bank (risk taking behavior) dalam penyaluran kredit

\section{METODE PENELITIAN}

Studi ini menguji secara empirik implikasi dari tingkat diversifikasi pendapatan perbankan terhadap stabilitas bank. Data yang digunakan adalah bank yang beroperasi dari tahun 2010 sampai 2015 dan sahamnya tercatat di bursa saham. Harga pasar saham menjadi ssalah satu variabel yang dibutuhkan untuk mengukur probabilitas kepailitan bank menggunakan model Merton yang digunakan dalam penelitian ini.

Penelitian ini menggunakan rerangka contingent claim dari Merton (1974) untuk mengukur risiko default sebuah bank. Model Merton ini memposisikan nilai ekuitas bank sebagai sebuah call option atas asset bank itu sendiri. Probabilitas terjadinya default diukur dengan menggunakan distance to default yaitu selisih antara nilai asset perusahaan dengan face value hutangnya.

Seperti yang ditunjukkan Merton (1974) nilai pasar ekuitas bank dapat dimodelkan sebagai sebuah call option atas asset bank tersebut:

$V_{E}=V_{A} e^{-d T} N\left(d_{1}\right)-X e^{-r T} N\left(d_{2}\right)+\left(1-e^{-d T}\right) V_{A} \ldots \ldots . .(4)$

$d_{1}=\frac{\log \left(\frac{V_{A}}{X}\right)+\left(r-d+\frac{S_{A}}{2}\right) T}{S_{A} \sqrt{ } T}: d_{2}=d_{1}-S_{A} \sqrt{T} \ldots$.

Persamaan (4) adalah Black-Scholes-Merton Option formula untuk call option. $V_{A}$ adalah nilai pasar aset bank, $V_{E}$ adalah nilai pasar ekuitas bank. $X$ adalah Face Value hutang bank yang jatuh tempo pada waktu $T$ dan diinterpolasi secara linier untuk setiap titik harian pada suatu periode dengan menggunakan rata-rata posisi awal tahun dan akhir tahun. Metode ini perlu dilakukan agar diperoleh proses nilai asset yang smooth dan menghindari lonjakan (jumps) pada implied probabilitydefault yang dihasilkan. $r$ adalah suku bunga bebas risiko bulanan, dan $d$ adalah persentase dividen terhadap $V_{A} \cdot V_{S}$ adalah volatilitas nilai aset bank yang karena tidak observable didekati dengan persamaan berikut (Anginer et al., 2014):

$S_{E}=\frac{V_{A e^{-d T}} N\left(d_{1}\right) S_{A}}{V_{E}}$
$S_{E}$ adalah standar deviasi imbal hasil saham bank secara harian selama setahun sebelumnya. $\mathrm{T}$ sama dengan 1 tahun. $\mathrm{r}$ adalah imbal hasil Surat Utang Negara Republik Indonesia yang jatuh tempo satu tahun. X Dengan dua buah variabel yang dapat dihitung dari data pasar saham yaitu dan $V_{E}$ dan $S_{E}$ dan $X$ yang diperoleh dari laporan keuangan bank, kita dapat memecahkan masalah estimasi terhadap danyang unobservable dengan menggunakan metode Newton untuk persamaan (3) dan (4) secara bersamaan. Nilai awal yang dimasukkan dalam proses iterasi Newton: $V_{A}=V_{E}+X$ dan $S_{A}=S_{E} V_{E} /\left(V_{E}+X\right)$. Proses iterasi dilakukan dengan menggunakan program optimasi Solver pada Microsoft Excel. Metode interpolasi ini dilakukan agar proses perubahan nilai pasar asset perusahaan menjadi lebih mulus dan menghindari adanya lonjakan probability default pada akhir tahun (Anginer et al., 2014). Pada perhitungan volatilitas asset $\left(S_{A}\right)$ dilakukan winsorized untuk $S_{E}$ dan $V_{E} /\left(V_{E}+X\right)$ pada level persentil 5\% dan $95 \%$ dengan tujuan mengurangi pengaruh dari pencilan (outlier).

Setelah kita berhasil mengestimasi besarnya nilai pasar asset bank dan volatilitasnya dan mengasumsikan besarnya m yaitu equity premium sebesar 6\% seperti yang digunakan juga oleh Anginer et al. (2014) maka kita dapat menghitung besarnya Merton's distance-to-default sebagai berikut:

$$
d d=\frac{\log \left(\frac{V_{A}}{X}\right)+\left(m-d+\frac{s_{3}^{2}}{2}\right) T}{s_{A} \sqrt{T}}
$$

Probabilitas default bank adalah transformasi normal dari distance to default yaitu $\mathrm{PD}=\mathrm{F}(-\mathrm{dd})$, dimana $\mathrm{F}$ adalah fungsi distribusi kumulatif dari sebuah distribusi normal standard. Perhitungan distance-to-default untuk masing-masing bank dilakukan setiap bulan sepanjang periode penelitian.

Untuk mengukur tingkat diversifikasi pendapatan bank, studi ini menggunakan ukuran konvensional berupa Focus Index yang merupakan sebuah Herfindahl-Hirschman Index (HHI). Seperti yang digunakan oleh Stiroh dan Rumble (2006) serta Sanya dan Wolfe (2011), Income Focus Index ini mengukur seberapa fokus dan spesialisasi bank dalam aktivitas perolehan pendapatannya.Focus Index dihitung dengan prosedur sebagai berikut: pertama, persentase dari setiap jenis pendapatan terhadap total pendapatan bank dihitung dengan rumus yang ada pada persamaan (8). $X_{i, t}^{j}$ adalah eksposure nominal (jumlah pendapatan) bank i pada periode $\mathrm{t}$ terhadap aktivitas $\mathrm{j}$, dimana $\mathrm{j}=1, \ldots, \mathrm{n}$. besarnya $\mathrm{n}$ tergantung scope aktivitas setiap bank. 
$R E_{i, t}^{j}$ mencerminkan relative exposure dari setiap aktivitas bank:

$$
R E_{i, t}^{j}=\frac{x_{i, t}^{j}}{\sum_{j=1}^{n} x_{i, t}^{j}} .
$$

Langkah kedua adalah menghitung Income Focus Index melalui formula sebagai berikut:

Income Focus Index $x_{i, t}=\sum_{j=1}^{n} R E_{i, t}^{j}$

Semakin tinggi Income Focus Index menunjukkan semakin fokusnya bank tersebut pada sebuah aktivitas bank saja; diversifikasi pendapatan bank tersebut rendah.

Capital buffer adalah ukuran kekuatan modal bank dalam meredam munculnya risiko yang dapat mengancam stabilitas bank. Sesuai dengan Basel II, rasio kebutuhan modal minimum sebesar $8 \%$ dari aktiva tertimbang menurut risiko (ATMR). Kebutuhan modal minimum ini dipersyaratkan untuk risiko kredit, pasar dan operasional. Secara sederhana formula rasio kebutuhan modal ini dituliskan sebagai berikut :

$$
\mathrm{CAR}=\frac{\text { Modal }}{\text { ATMR }}
$$

dimana,

CAR : Capital Adequacy Ratio/ KPMM

(Kewajiban Penyediaan modal minimum)

ATMR : Aktiva Tertimbang menurut Risiko (Risiko Kredit, Pasar dan Operasional)

Capital buffer adalah selisih antara rasio modal yang dimilik oleh bank dengan kebutuhan modal minimum yang dipersyaratkan yakni $8 \%$. Capital buffer dirumuskan sebagai berikut :

$$
\mathrm{BUF}=\mathrm{K}_{\mathrm{it}}-\mathrm{K}_{\mathrm{it}}^{\mathrm{r}}
$$

dimana,

BUF adalah capital buffer

$\mathbf{K}_{\mathrm{i}, \mathrm{t}}$ adalah rasio kecukupan modal bank i pada tahun ke $\mathrm{t}$

$\mathbf{K}_{\mathbf{i}, \mathbf{t}}^{\mathrm{R}}$ adalah rasio kecukupan modal minimum sesuai persyaratan regulator

Uji empirik hubungan antara probabilita kebangkrutan dengan diversifikasi pendapatan ditambah NPL, LDR dan capital buffer bank sebagai variabel kontrol. LDR menunjukkan agresifitas bank dalam menyalurkan kredit, NPL menunjukkan kemampuan bank dalam memilah calon nasabah penerima kredit yang disalurkannya. Uji empirik dilakukan melalui model berikut:
$P_{\text {it }}=\alpha+\beta_{1}$ Inc Focus $_{\text {it }}+\beta_{2}$ Inc Focusit $+\gamma$ LDR $_{\text {it }}+\lambda N P_{\text {it }}+\theta$ Cap BUFFER $R_{\text {it }}+\lambda_{1} D_{1}+$ $\lambda_{2} D_{2}+\lambda_{3} D_{3}+e_{i t}$

$P_{i t}$ adalah probabilita kebangkrutan atau kepailitan bank. Bentuk hubungan antara diversifikasi pendapatan dan probabilita kebangkrutan bank akan berbentuk $U$ shaped apabila koefisien $\beta_{2}$ signifikan secara statistik dan bernilai positif.

$D$ adalah sebuah variable dummy, $D_{1}=1$ jika bank i termasuk bank BUMN dan nol untuk bank lainnya, $D_{2}=1$ jika bank i termasuk bank Swasta Nasional dan nol untuk bank lainnya, $D_{3}=1$ jika bank i termasuk bank Asing dan nol untuk bank lainnya,

Untuk mengestimasi persamaan di atas digunakan regresi data panel Generalized Least Square (GLS) random effect. Metode ini dipilih karena GLS random effect dapat mengatasi masalah heteroskedastisitas yang ada pada data perbankan. Karakteristik sektor perbankan yang terdiri dari beberapa kelompok bank berdasarkan besar asset, segmen pasar yang dilayani sehingga umumnya selalu perlu diantisipasi adanya masalah hetersoskedastisitas seperti yang dinyatakan oleh Anginer et al. (2014) Selanjutnya, secara parsial masing-masing variabel bebas akan diuji apakah berpengaruh secara signifikan terhadap variabel tidak bebas. Selain itu, pada model tersebut, nilai $R$ Squared akan menjelaskan seberapa besar informasi pada variabel bebas dapat menjelaskan variabel tidak besar.

Menurut literatur ekonometrika data panel yang terbaru seperti Wooldridge (2012), pemilihan model panel antara fixed effect dan random effect berasal dari asumsi atas unobserved effect misalnya produktivitas, efisiensi, dan loyalitas konsumen yang tidak dimasukkan ke dalam model. Apabila unobserved effect tidak berubah antar individu atau kelompok yang ada dalam data, atau berubah antar waktu maka model panel yang dipilih adalah fixed effect. Sementara apabila unobserved effect berubah antar individu atau antar waktu maka random effect yang dipilih. Pendekatan lebih praktis diambil berdasarkan pernyataan Gujarati dan Porter (2008) bahwa jika jumlah cross section banyak dan time series relative sedikit maka random effect lebih tepat untuk digunakan dari pada fixed effect. Taylor (1980) membuktikan jika T>3 dan N-K > 9 dimana $\mathrm{K}$ adalah jumlah regresor maka Random Effect Model sebaiknya digunakan. Pada penelitian saya $\mathrm{T}=10$ dan $\mathrm{N}=110, \mathrm{~K}=5$, jadi pemilihan alasan lebih kuat. Uji Hausman sebagai uji formal pemilihan model data panel antara fixed effect dan random effect memperkuat pilihan atas model random effect. 


\section{HASIL DAN PEMBAHASAN}

Hasil perhitungan distance-to-default perbankan Indonesia dapat dilihat pada Tabel 2. Pada Tabel 2 dapat dilihat statistik deskriptif data runtun waktu nilai distance-to-default dari semua bank yang diobservasi secara bulanan sejak Januari 2010 sampai Desember 2014. Distance to default menunjukkan selisih antara nilai pasar asset terhadap nilai pokok hutang yang diskala dengan standar deviasi nilai pasar asset bank. Setelah memperoleh nilai Merton's distance-to-default dapat dihitung probabilitas terjadinya default dari masing-masing bank secara bulanan pada periode observasi. Hasil perhitungan probability of default dapat dilihat pada Tabel 3. Standar deviasi probability of default yang sangat besar pada semua bank pada periode 2010 sampai 2014 menunjukkan perbankan Indonesia mengalami turbulensi yang sangat tinggi dimana siklus bisnis dan kondisi perekonomian menyebabkan risiko kebangkrutan bank naik turun secara fluktuatif dengan simpangan yang sangat besar walaupun secara rata-rata dan median, probability of default setiap bank dapat dikatakan berada pada posisi yang masih cukup manageable.

Tabel 2. Hasil Perhitungan Merton's Distance-to-Default Bulanan periode 2010-2014

\begin{tabular}{lccccc}
\hline Nama Bank & Mean & \multicolumn{1}{l}{ Median } & Maximum & Minimum & Std. Dev. \\
\hline Mandiri & -0.2655 & -0.78127 & 1.05257 & -1.90994 & 1.00453 \\
BRI & -1.97662 & -0.83494 & 0.18288 & -30.304 & 3.97842 \\
BCA & 0.18761 & 0.14216 & 1.06519 & -1.26701 & 1.01809 \\
BNI & -0.59922 & 0.04803 & 1.35721 & -7.0196 & 2.0259 \\
CIMB Niaga & -0.20849 & -0.06602 & 1.06178 & -4.57107 & 1.33889 \\
Danamon & 0.11768 & 0.22401 & 1.10353 & -1.40621 & 0.8643 \\
Permata & -0.8319 & -0.38788 & 1.77467 & -10.2526 & 2.00762 \\
Pan & -0.04508 & 0.13633 & 1.9154 & -3.78859 & 1.05148 \\
Maybank & 0.15439 & 0.33714 & 2.53253 & -5.2337 & 1.34103 \\
OCBC NISP & -0.12065 & 0.06235 & 1.63702 & -3.38739 & 1.06391 \\
Bukopin & -7.27824 & -1.45716 & 3.78307 & -2.73769 & 2.99475 \\
BTPN & 0.83703 & 0.76429 & 2.20834 & -0.95299 & 0.66313 \\
Mega & -3.22387 & 0.26498 & 2.67928 & -22.1366 & 2.66688 \\
Mayapada & 0.03009 & 0.29093 & 2.02577 & -10.4157 & 3.64849 \\
Artha Graha & -3.48065 & -2.05645 & 2.59464 & -20.0246 & 3.86885 \\
Victoria & -3.03195 & -1.68596 & 1.64831 & -16.2737 & 3.68698 \\
QNB & 1.20061 & 0.57844 & 4.65111 & -0.92105 & 1.47912 \\
Woori Saudara & 0.18493 & 0.3203 & 1.02123 & -2.57728 & 0.56714 \\
Windu Kentjana & -0.54411 & -0.22933 & 2.31324 & -7.99442 & 1.35901 \\
MNC Internasional & 0.44923 & -0.75952 & 3.90828 & -9.31776 & 3.3406 \\
Capital Indonesia & -0.65742 & -0.49278 & 3.10445 & -5.95892 & 1.6566 \\
Pundi Indonesia & -0.36497 & -0.04029 & 1.67396 & -5.66805 & 1.32404 \\
BRI Agroniaga & -0.06663 & 0.07408 & 2.27241 & -3.32697 & 0.85511 \\
Bumi Arta & -2.73896 & -1.36807 & 1.79368 & -14.1177 & 3.28313 \\
\hline Sumber: Hail pengof & & & & &
\end{tabular}

Sumber: Hasil pengolahan data penelitian

Probabilitas default mengalami lonjakan besar pada periode tahun 2007 dan 2008 sebagai imbas terjadinya krisis keuangan di Amerika Serikat yang berdampak sangat luas terhadap perekonomian dunia. Beberapa bank besar di Amerika Serikat, perusahaan asuransi dan investment bank turut mengalami kepailitan yang terjadi secara massif dan massal. Hal ini turut menyebabkan meningkatnya probabilitas kepailitan perbankan Indonesia, bahkan di antaranya tercatat probabilita nya lebih atau mendekati $90 \%$. Standar deviasi dari probaiita kepailitan yang sangat besar menunjukkan besarnya probabilita kemungkinan sebuah bank gagal mengalami fluktuasi yang sangat besar pada periode yang diobservasi. Standar deviasi yang besar menjadi indikasi relative rentannya perbankan Indonesia 
Tabel 3

Hasil Perhitungan Merton's Probability of DefaultBulanan periode 2010-2014

\begin{tabular}{llllll}
\hline Nama Bank & Mean & Median & Maximum & Minimum & Std. Dev. \\
\hline Mandiri & 0.395312 & 0.217322 & 0.853731 & 0.02807 & 0.842438 \\
BRI & 0.240402 & 0.201876 & 0.572554 & $5.1 \mathrm{E}-202$ & 0.999965 \\
BCA & 0.574409 & 0.556523 & 0.856605 & 0.102576 & 0.845682 \\
BNI & 0.274513 & 0.519154 & 0.912643 & $1.11 \mathrm{E}-12$ & 0.978612 \\
CIMB Niaga & 0.417423 & 0.473681 & 0.855832 & $2.43 \mathrm{E}-06$ & 0.909697 \\
Danamon & 0.546839 & 0.588625 & 0.865101 & 0.079831 & 0.806288 \\
Permata & 0.202733 & 0.349052 & 0.962024 & $5.76 \mathrm{E}-25$ & 0.977658 \\
Pan & 0.482022 & 0.55422 & 0.972279 & $7.58 \mathrm{E}-05$ & 0.853481 \\
Maybank & 0.561349 & 0.631994 & 0.994338 & $8.31 \mathrm{E}-08$ & 0.910045 \\
OCBC NISP & 0.451984 & 0.524858 & 0.949187 & 0.000353 & 0.856315 \\
Bukopin & $1.69 \mathrm{E}-13$ & 0.072536 & 0.999923 & 0.003094 & 0.998627 \\
BTPN & 0.798712 & 0.777653 & 0.98639 & 0.170298 & 0.746376 \\
Mega & 0.000632 & 0.604488 & 0.996311 & $7 \mathrm{E}-109$ & 0.996172 \\
Mayapada & 0.512002 & 0.614448 & 0.978606 & $1.05 \mathrm{E}-25$ & 0.999868 \\
Artha Graha & 0.00025 & 0.01987 & 0.995265 & $1.68 \mathrm{E}-89$ & 0.999945 \\
Victoria & 0.001215 & 0.045902 & 0.950355 & $7.58 \mathrm{E}-60$ & 0.999887 \\
QNB & 0.885049 & 0.718516 & 0.999998 & 0.178512 & 0.930446 \\
Woori Saudara & 0.573358 & 0.62563 & 0.846427 & 0.004979 & 0.71469 \\
Windu Kentjana & 0.293183 & 0.409306 & 0.989645 & $6.51 \mathrm{E}-16$ & 0.912928 \\
MNC Internasional & 0.673367 & 0.223771 & 0.999954 & $5.94 \mathrm{E}-21$ & 0.999582 \\
Capital Indonesia & 0.255455 & 0.311084 & 0.999047 & $1.27 \mathrm{E}-09$ & 0.9512 \\
Pundi Indonesia & 0.357567 & 0.483931 & 0.952931 & $7.22 \mathrm{E}-09$ & 0.907255 \\
BRI Agroniaga & 0.473438 & 0.529527 & 0.988469 & 0.000439 & 0.803755 \\
Bumi Arta & 0.003082 & 0.085645 & 0.963568 & $1.48 \mathrm{E}-45$ & 0.999487 \\
\hline Sumbr:Han & & & &
\end{tabular}

Sumber: Hasil pengolahan data penelitian

terhadap perubahan faktor-faktor perekonomian makro. Apabila ditinjau dari rata-rata probabilita kebangkrutan yang masih di bawah 50\% sebetulnya dapat dinyatakan secara umum perbankan Indonesia masih cukup stabil.

Hasil pengukuran tingkat diversifikasi pendapatan bank dengan Income Focus Index dapat dilihat pada Tabel 4. Diversifikasi pendapatan tertinggi ada pada bank BUMN yang memiliki product lines dan jenis jasa perbankan yang paling lengkap serta pendapatan dari setiap produk dan jasa yang relatif lebih merata dibandingkan dengan BPD dan bank campuran yang fokus pada beberapa jenis jasa bank tertentu saja. Bank Asing memiliki diversifikasi pendapatan yang paling buruk dibandingkan dengan kelompok bank lainnya karena bank asing umumnya memiliki strategi bisnis yang spesifik dengan fokus pada jasa non tradisional.
Perbedaan tingkat diversifikasi antar jenis bank dapat menjadi indikasi kuat bahwa pasar perbankan Indonesia sangat segmented, setiap bank memiliki segmen pasarnya masing-masing dan mampu melayani segmen pasarnya tersebut dengan baik sehingga segmen pasarnya tersebut dapat dikatakan cukup loyal sehingga semua bank dapat tetap eksis dalam jangka yang cukup panjang. Hal ini diperkuat dengan selisih SBDK di perbankan Indonesia yang jauh lebih tinggi dibandingkan dengan SBDK negara-negara tetangga (Tabel 5 dan Tabel 6).

Rendahnya tingkat persaingan antar bank di Indonesia dapat dengan jelas ditunjukkan dari tingginya suku bunga dasar (SBDK) perbankan Indonesia dibandingkan yang ada di negara tetangga. Rata-rata SBDK perbankan Indonesia tahun 2015 mencapai 10,7\% untuk kredit yang diberikan kepada korporasi dibandingkan dengan 
Tabel 4. Diversifikasi Pendapatan Berdasarkan Kelompok Bank di Indonesia

\begin{tabular}{lllllll}
\hline \multirow{2}{*}{ Periode } & $\begin{array}{l}\text { Semua } \\
\text { Bank }\end{array}$ & $\begin{array}{l}\text { Bank } \\
\text { BUMN }\end{array}$ & $\begin{array}{l}\text { Bank } \\
\text { Swasta } \\
\text { Nasional }\end{array}$ & $\begin{array}{l}\text { Bank } \\
\text { Campuran }\end{array}$ & $\begin{array}{l}\text { Bank } \\
\text { Asing }\end{array}$ & BPD \\
\hline 2014 & 0.2291 & 0.1255 & 0.1801 & 0.3198 & 0.5295 & 0.4040 \\
2013 & 0.2526 & 0.1297 & 0.2112 & 0.3283 & 0.5105 & 0.4655 \\
2012 & 0.2634 & 0.1799 & 0.2122 & 0.3303 & 0.5350 & 0.4313 \\
2011 & 0.2587 & 0.1620 & 0.2172 & 0.3148 & 0.5401 & 0.4040 \\
2010 & 0.2612 & 0.1562 & 0.2189 & 0.2884 & 0.5426 & 0.4258 \\
2009 & 0.2454 & 0.1587 & 0.1932 & 0.2366 & 0.5544 & 0.3951 \\
2008 & 0.1614 & 0.0948 & 0.1114 & 0.1875 & 0.4625 & 0.2739 \\
2007 & 0.1593 & 0.0925 & 0.1241 & 0.1981 & 0.4231 & 0.2381 \\
2006 & 0.1442 & 0.0788 & 0.1085 & 0.1721 & 0.4068 & 0.2225 \\
2005 & 0.1467 & 0.0851 & 0.1127 & 0.1564 & 0.3695 & 0.2412 \\
\hline Rata-rata & 0.212 & 0.126 & 0.169 & 0.253 & 0.487 & 0.350 \\
\hline Jumlah & 1030 & 40 & 510 & 130 & 100 & 250 \\
\hline Observasi & 0.1030 & & &
\end{tabular}

Sumber: Bank Indonesia (diolah)

Tabel 5. Suku Bunga Dasar Kredit Perbankan Indonesia Periode 2001-2011(\%)

\begin{tabular}{llll}
\hline & Kredit & Kredit & Kredit \\
& Korporasi & Ritel & Mikro \\
\hline Rata-rata & 10.70 & 11.65 & 14.04 \\
Median & 10.75 & 11.65 & 13.43 \\
Standard Deviation & 2.09 & 1.92 & 4.53 \\
\hline
\end{tabular}

Sumber: Otoritas Jasa Keuangan, 2015

Tabel 6. Suku Bunga Dasar Kredit Malaysia, Thailand dan Philipines Periode 2001-2011 (\%)

\begin{tabular}{lccc}
\hline & Malaysia & Thailand & Philippines \\
\hline Rata-rata & 3.99 & 6.75 & 5.35 \\
Median & 3.95 & 6.55 & 5.05 \\
Standard Deviation & 0.35 & 0.57 & 0.75 \\
\hline Sumber: Bank Negara Malaysia, Bank of Thailand, dan Bank Sentral of Philippines, 2015
\end{tabular}

Malaysia misalnya yang hanya 3,99\% saja. Tingkat suku bunga dasar kredit memang tidak dapat dibandingkan begitu saja antar Negara karena biaya dana (cost of fund) yang ditanggung oleh bank di setiap negara berbeda besarnya tergantung pada tingkat inflasi setiap Negara. Namun apabila kita lihat standar deviasi dari SBDK masing-masing Negara, standar deviasi SBDK perbankan Indonesia paling tinggi. Tingginya standar deviasi menunjukkan dispersi atau sebaran SBDK antar bank sangat lebar yang menunjukkan indikasi adanya segmented banking market yang cukup ketat di Indonesia, bank melayani segmen psarnya sendiri-sendiri sehingga memiliki market power yang relative besar dan dapat menetapkan suku bunga kredit yang dapat jauh berbeda dengan bank lainnya.

Uji Hausman dapat dilihat pada Tabel 7 yang menunjukkan model data panel yang sebaiknya digunakan adalah model Random Effect. Tabel 8menampilkan hasil uji signifikansi hubungan probability of default setiap bank dengan diversifikasi pendapatan yang diukur dengan Income 
fokus Index yang diestimasi dengan menggunakan model Random Effect. Seluruh variable terbukti signifikan pada tingkat error $5 \%$ dan $1 \%$ dengan sign koefisien yang positif berarti semakin tinggi NPL, LDR, dan Capital Buffer sebuah bank maka probability of defaultnya cenderung tinggi. Variable income focus signifikan baik pada bentuk kuadratnya maupun pada data levelnya. Koefisien $\beta_{2}$ terbukti signifikan dan bertanda positif sehingga dapat disimpulkan bahwa hubungan antara tingkat diversifikasi dan probability of default bersifat kuadratik berbentuk menyerupai huruf $\mathrm{U}$ (parabola). Diversifikasi pendapatan pada awalnya dapat menurunkan probabilita kebangkrutan namun sampai suatu titik (inflection point), tingkat diversifikasi yang semakin meningkat justru mendorong probabilita kebangkrutan naik dengan pesat. Temuan ini berbeda dengan temuan Meslier et al. (2014) di Filipina, namun sejalan dengan yang ditemukan oleh DeYoung dan Torna (2013) di perbankan Amerika Serikat dan Lepetit et al. (2008) di perbankan Eropa.

Tabel 7. Hasil Hausman Test

\begin{tabular}{lllll}
\hline & Koefisien & & & \\
\cline { 2 - 5 } & (b) & (B) & (b-B) & sqrt(diag(V_b-V_B $))$ \\
\hline Buf & 1.678389 & 1.439311 & 0.239078 & 0.0110412 \\
IncFoc & 5.145778 & 5.811323 & -0.665550 & 0.1346111 \\
IncFoc2 & 5.813251 & 5.726908 & 0.086343 & 0.1311643 \\
LDR & 1.811316 & 1.058717 & 0.752599 & 0.0364112 \\
NPL & 8.112238 & 8.012162 & 0.100076 & .24875812 \\
\hline
\end{tabular}

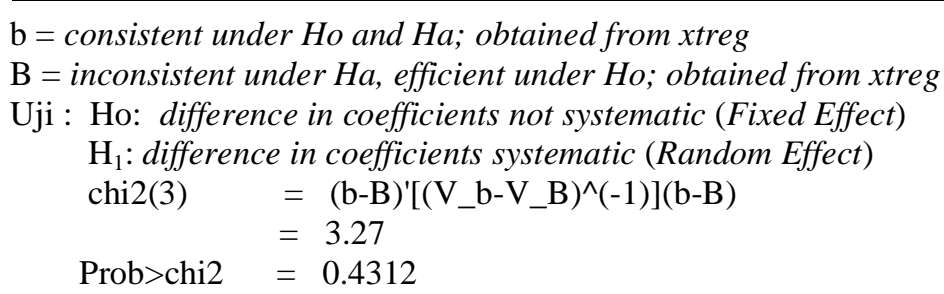

NIM juga berhubungan signifikan positif dengan probability of default sehingga dapat disimpulkan bahwa apabila sebuah bank memiliki market power yang besar sehingga dapat menetapkan pricing yang agresif dengan NIM yang tinggi akan mendorong bank tersebut menjadi kurang disiplin dalam menyalurkan kredit yang mengakibatkan probability of default nya cenderung meningkat. Hubungan yang positif antara NIM dan probability of default dapat juga disebabkan terjadinya adverse selection yang dialami bank karena bunga kredit yang terlampau tinggi justru menyebabkan perusahaan yang mengajukan kredit dan memperoleh penyaluran kredit dari bank adalah mereka yang berisiko tinggi, sementara perusahaan yang memiliki profil risiko yag lebih rendah memilih sumber pembiayaan selain bank. LDR juga berhubungan positif signifikan dengan probability of default, yang menunjukkan daya dukung deposito terhadap jumlah kredit yang disalurkan turut mempengaruhi besarnya risiko kebangkrutan bank.
NPL berhubungan signifikan positif dengan probability of default sehingga dapat disimpulkan bahwa semakin tingginya NPL yang sekaligus menunjukkan juga bank'srisk taking behavior dan kemampuan mengelola pemberian kredit menjadi ancaman serius kepailitan bank. Argumen bank'srisk taking behavior juga dapat digunakan untuk memahami hubungan positif signifikan antara capital buffer dan probability of default. Bank yang memiliki capital buffer yang tinggi justru memiliki probability of default yang lebih tinggi. Sebuah bank yang memiliki capital buffer yang besar cenderung lebih berani mengambil risiko sehingga menetapkan pricing yang agresif dengan NIM yang tinggi akan mendorong bank tersebut menjadi kurang disiplin dalam menyalurkan kredit yang mengakibatkan probability of default nya cenderung meningkat. LDR juga berhubungan positif signifikan dengan probability of default, yang menunjukkan daya dukung deposito terhadap jumlah kredit yang disalurkan turut mempengaruhi 
64 Matrik: Jurnal Manajemen, Strategi Bisnis dan Kewirausahaan Vol. 11, No. 1, Februari 2017

Tabel 8. Hasil Uji Model Empirik

\begin{tabular}{|c|c|}
\hline Variabel & $\begin{array}{l}\text { Koefisien } \\
\text { (t statistics) }\end{array}$ \\
\hline Konstanta & $\begin{array}{l}0,18 * * * \\
(7,58)\end{array}$ \\
\hline Income Focus Index & $\begin{array}{l}5,81 * * \\
(3,99)\end{array}$ \\
\hline Income Focus Index Kuadrat & $\begin{array}{l}5,72 * * \\
(5,69)\end{array}$ \\
\hline LDR & $\begin{array}{l}1,81 * * \\
(1,89)\end{array}$ \\
\hline NPL & $\begin{array}{l}8,01 * * \\
(2,39)\end{array}$ \\
\hline Capital Buffer & $\begin{array}{l}1,43^{*} \\
(1,69)\end{array}$ \\
\hline Dummy BUMN & $\begin{array}{l}(0,23)^{*} \\
(1,89)\end{array}$ \\
\hline Dummy Swasta Nasional & $\begin{array}{l}(0,44)^{* *} \\
(2,35)\end{array}$ \\
\hline Dummy Bank Asing & $\begin{array}{l}(0,31)^{*} \\
(1,87)\end{array}$ \\
\hline R Squared & 0,87 \\
\hline Wald chi2 & 92,82 \\
\hline Prob>chi 2 & 0,000 \\
\hline
\end{tabular}

Sumber: Bank Indonesia (diolah)

besarnya risiko kebangkrutan bank. LDR juga menunjukkan agresivitas bank dalam menyalurkan kredit, agresivitas ini lah yang menyebabkan probabilita kebangkrutan bank menjadi meningkat.

Dummy variable semuanya menunjukkan signifikansi yang cukup baik dengan tanda positif, hal ini menunjukkan adanya perbedaan besarnya probabilita kepailitan antar kelompok bank dan pengaruh diversifikasi pendapatan terhadap probabilita kepailitan yang berbeda-beda. Kelompok bank swasta nasional memiliki probabilita kepailitan yang paling besar dibandingkan dengan kelompok bank lain. Sementara itu, bank BUMN walaupun memiliki tingkat diversifikasi pendapatan yang tertinggi dibandingkan dengan kelompok bank lainnya memiliki probabilita kepailitan yang relatif lebih rendah, dimana hal ini menunjukkan bank-bank BUMN lebih mampu mengelola penyaluran dan pengawasan kreditnya serta diversifikasi yang dilakukan oleh bank-bank BUMN lebih disebabkan oleh lingkup pelayanan bank yang melebar secara natural karena basis nasabahnya yang semakin luas dan beragam dari pada sebuah upaya peningkatan margin laba melalui transaksi bank yang non tradisional.

\section{SIMPULAN}

Diversifikasi pendapatan mempengaruhi probabilita kebangkrutan bank. Diversifikasi pendapatan yang muncul secara alamiah karena adanya permintaan dan kebutuhan nasabah bank yang jumlahnya semakin banyak dan beragam menyebabkan probabilita default bank mengalami penurunan. Turunnya probabilita ini dapat diduga karena fluktuasi total pendapatan bank dapat diredam oleh karena adanya fee based income. Kenaikan probabilita default bank bank baru terjadi ketika tingkat diversifikasi menjadi terlampau tinggi sehingga pola hubungan antara tingkat persaingan dan risiko kredit bank menjadi menyerupai huruf $U$, dimana kenaikan tingkat diversifikasi pendapatan pada awalnya membuat probabilita default bank menurun namun pada satu titik, diversifikasi yang terus meningkat justru menaikkan risiko bank. Diversifikasi pendapatan yang eksesif karena keterlibatan bank dalam aktivitas trading surat berharga, sekuritas derivative, dan aktivitas bank yang non tradisional mendorong peningkatan probabilita default bank. Bank menjadi lebih sensitif terhadap perubahan ekonomi dan siklus bisnis. 
Probabilita kegagalan bank terbukti berbeda antar kelompok bank. Bank swasta nasional cenderung memiliki probabilita default yang jauh lebih besar dari pada bank BUMN dan bank asing. Bank BUMN memiliki probabilita default yang paling rendah. Diversifikasi yang dilakukan oleh bankbank BUMN lebih disebabkan oleh lingkup pelayanan bank yang melebar secara natural karena basis nasabahnya yang semakin luas dan beragam dari pada sebuah upaya peningkatan margin laba melalui transaksi bank yang non tradisional. Hal ini diperkuat dengan NPL, LDR, dan capital buffer yang terbukti berhubungan signifikan positif terhadap probabilita default. Ketiga variable yang mencerminkan agresivitas bank dalam menyalurkan kredit tersebut terbukti lebih besar pada kelompok bank swasta nasional dibandingkan kelompok bank yang lain.

\section{REFERENSI}

Afik, Z., Arad, O.,\& Galil, K .(2016). Using Merton model for default prediction: An empirical assessment of selected alternatives, Journal of Empirical Finance 35, 43-67

Altman, E. (1968).Financial Ratios, Discriminant Analysis and the Prediction of Corporate Bankruptcy. Journal of Finance, 189-209.

Anginer, D., Demirguc-Kunt, A., \& Zhu, M. (2014). How does competition affect bank systemic risk? Journal of Financial Intermediation, 1-26.

Beaver, W. H. (1966). Market prices, financial ratios, and the prediction of failure. Journal of Accounting Research, 6(2), 179-182.

Beck, T., Jonghe, O. D., \& Schepens, G. (2012). Bank competition and stability: Cross-country heterogeneity. Journal of Financial Intermediation, 218-244.

Berger, AN., Klapper, L., \& Turk-Ariss, R. (2009). Bank Competition and Financial Stability, Journal of Financial Services Research, vol. 35(2), pages $99-118$

Berger, A.N.(1995). The Relationship Between Capital and Earnings in Banking, Journal of Money, Credit and Banking, 27, 432-56.

Berger, A.N., Demirguc-Kunt, A., Levine, R., \& Haubrich, J (2004), Bank concentration and competition: An evolution in the making, Journal of Money, Credit and Banking 36, 433-451.

Berger, A.N., R. DeYoung, M.J. Flannery, D. Lee, \& Oztekin, O. (2008), How do large banking organizations manage their capital ratios?, Federal Reserve working paper.
Boyd, J., \& De Nicolo, G (2005), The Theory of Bank Risk Taking Revisited, Journal of Finance 60, 1329-1343.

Boyd, J., G. De Nicolo, \& A.M. Jalal, (2006), Bank risk taking and competition revisited: New Theory and Evidence, IMF Working paper, $\mathrm{WP} / 06 / 297$.

Carletti, E., \& Hartmann, P. (2003), Competition and Financial Stability: What's Special about Banking?, In Monetary History, Exchange Rates and Financial Markets: Essays in Honour of Charles Goodhart, Vol. 2, edited by P. Mizen, Cheltenham, UK: Edward Elgar.

Carretta, A, V Farina, F Fiordelisi, P Schwizer, \& F S Stentella Lopes (2015) Don't Stand So Close to Me: The Role of Supervisory Style in Banking Stability, Journal of Banking \& Finance Vol 52, p 180-188

Cavallo, L., \& Rossi. S. (2001). Scale and Scope Economies in the European Banking systems, Journal of Multinational Management, Volume 11, Issues 4-5, 515-531

DeYoung, R., \& Torna, G., (2013). Nontraditional Banking Activities and Bank Failures During the Financial Crisis. Journal of Financial Intermediation 22, 397-421.

Edmister, R. (1972). An Empirical Test of Financial Ratio Analysis for Small Business Failure Prediction, The Journal of Financial and Quantitative Analysis, Vol. 7, No. 2, 1477-1493

Feng, G. \& Serlitis, A. (2010). Efficiency, Technical Change and Returns to Scale in Large U.S. Banks: Panel Data Evidence From an Output Distance Function Satisfying Theoretical Regularity. Journal of Banking and Finance, 34: 127-138.

Fernandez, A., Gonzalez, A., \& Suarez, N. (2016). Banking Stability, Competition and Economic Volatility. Journal of Financial Stability 22, p 101-120

Fu, X., Lin, Y., \& Molyneux, P.(2014)Bank Competition and Financial Stability in Asia Pacific,Journal of Banking \& Finance Vol 38 Pages 64-77

Ferreira Filipe, S., et al., (2016) Pricing default risk: The good, the bad, and the anomaly. Journal of Financial Stability, http://dx.doi.org/ 10.1016/j.jfs.2016.07.001

Gujarati, D. and Porter, W (2008) Basic Econometrics, McGraw Hill 5 th edition, New York

Hadad, M., Santoso, W., \& Sarwedi, B (2004) Model Prediksi Kepailitan Bank Umum di Indonesia, Bank Indonesia Research Paper, Direktorat 
Penelitian dan Peraturan Perbankan Bank Indonesia

Hellmann, Thomas, Kevin C. Murdock, and Joseph E. Stiglitz, (2000), Liberalization, Moral Hazard in Banking, and Prudential Regulation: Are Capital Requirements Enough? American Economic Review, 90 (1), 147-165

Hovakimian, A., Kayhan, A.\& Titman, S. (2012).Are corporate default probabilities consistent with the static tradeoff theory? Review of Financial Studies, 2012, vol 25, No. 2, 315-340.

Keeley, M. (1990), Deposit Insurance, Risk and Market Power in Banking, American Economic Review, December, 1183-1200.

Lepetit, L., Nys, E., Rous, P., \& Tarazi, A., (2008). Bank Income Structure And Risk: An Empirical Analysis of European Banks. Journal of Banking and Finance 32, 1452-1467.

Martin, D.,(1996) Early Warning of Bank Failure: A Logit Regression Approach, Journal of Banking and Finance, 249-276

Mercieca, S., Schaeck, K., \& Wolfe, S.(2007). Small European banks: benefits from diversification? Journal of Banking and Finance 31, 1975-1998

Merton, R. (1974). On the pricing of corporate debt: the risk structure of interest rate. Journal of Finance, 449-470.

Meslier, C., Tacneng, R., \& Tarazi, A. (2014)Is Bank Income Diversification Beneficial? Evidence From an Emerging Economy, Journal of International Financial Markets, Institutions and Money 31 97-126

Nguyen, M., Skully, M., \& Perera, S., (2012). Market power, revenue diversification and bank stability: Evidence from selected SouthAsian countries. Journal of International Financial Markets, Institutions and Money 22, 897-912

Ohlson, J. A. (1980). Financial ratios and the probabilistic prediction of bankruptcy. Journal of Accounting Research, New York: 18(1), 109-131

Schaeck, K, Cihak, M., \& Wolfe, S(2009), Are More Competitive Banking Systems More Stable?, Journal of Money, Credit and Banking, vol. 41(4), pages 711-734, 06

Stiglitz, J.E., \& Weiss, A, (1981).Credit Rationing in Markets With Imperfect Information, American Economic Review, Vol. 71, 393-410.

Stiroh, K.J.(2006). New Evidence On The Determinants of Bank Risk. Journal of Financial Service Research 30, 237-263.

Stiroh, K.J., \& Rumble, A. (2006). The Dark Side of Diversification: The Case of U.S. Financial Holding Companies. Journal of Banking and Finance 30, 2131-2161.

Sundaresan, S., 2013. A Review of Mertons Model of the Firms Capital Structure with itsWide Applications. Annual Review of Financial Economics, 5, 21-41.

Taffler, R J. (1982). Forecasting Company Failure in the UK Using Discriminant Analysis and Financial Ratio Data, Journal of the Royal Statistical Society. Series A, Vol. 145, No. 3, 342-358

Taylor, W E. (1980) Small Sample considerations in the estimation from Panel Data, Journal of Econometrics, vol 13, p 203-223

Wooldridge, J (2012) Econometric Analysis of Cross Section and Panel Data, Massachussetts Institute of Technology, p 251 -252 